\title{
Tax Revenue and Disparity: How to Improvement Income Inequality in Islamic Perspective
}

\author{
Tulus Suryanto ${ }^{1}$ \\ Femei Purnamasari ${ }^{2}$ \\ Mohamad Kurniawan ${ }^{3}$ \\ ${ }_{1,2, s}$ Faculty of Economics and Islamic Business Raden Intan Lampung Islamic University (UIN Raden Intan \\ Lampung) - Indonesia \\ Email: tulussuryanto@yahoo.co.id \\ ¿Email:femeipurnamasari21@gmail.com \\ ${ }^{3}$ Email:iwanxiaomi@gmail.com
}

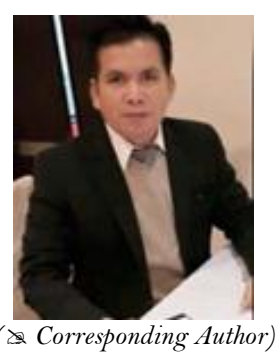

( Corresponding Author

\begin{abstract}
Tax revenue and income disparity Becomes attention and important study that need to be Analyzed, this is how tax revenues continue to increase it were an effect on income inequality in Indonesia. The magnitude of per capita income in Indonesia is the medium category with poor people have continued to rise in the last ten years. This research is to find out how the effect on the tax revenue with income disparity in Indonesia. Typically, the data that the data used is the panel that combines with a cross section of data and time series, starts from 2014-2016. Analysis that will uses in this research is double semi-log linear regression through Pooled Least Square with Fixed Effects Model (FEM) analysis, in conclusion the research finds that tax revenues has positive correlation with income disparity and will be reviewed restaurants by an Islamic perspective. Tax policy in the Islamic perspective gives important input to implement tax policy in Indonesia. In Islam's view, the tax for Muslims has been applied for reviews their own responsibilities and regulations, Islamic Also has been implement how the source and the collecting system, the system should have secured or make a guarantee that the rich people and the welfare people get bigger proportion (to pay tax) because welfare social order. The cost of the tax burden in society that will show equal and not too give strength if the cost that applied based on people's ability follows the tax system in Islam. Indeed, it can be a reason for decreasing inequality and poverty in each region.
\end{abstract}

Keywords: Tax revenue, Income disparity and Islamic perspective of tax.

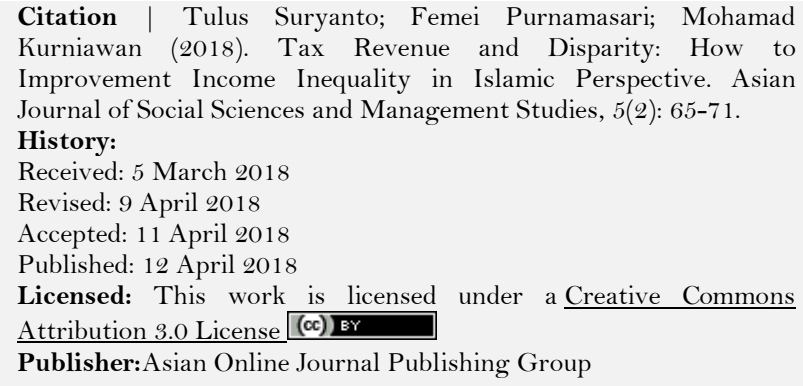

Contribution/Acknowledgement: All authors contributed to the conception and design of the study.

Funding: This study received no specific financial support

Competing Interests: The authors declare that they have no conflict of interests.

Transparency: The authors confirm that the manuscript is an honest, accurate, and transparent account of the study was reported; that no vital features of the study have been omitted; and that any discrepancies from the study as planned have been explained.

Ethical: This study follows all ethical practices during writing.

\section{Contents}

1. Background

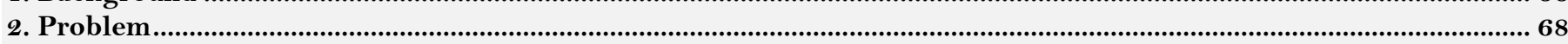

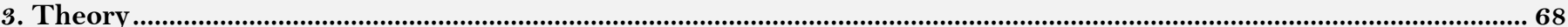

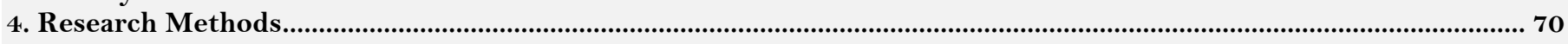

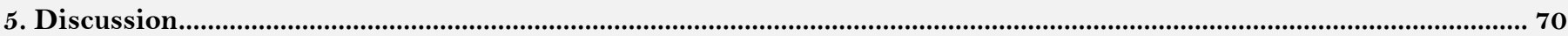

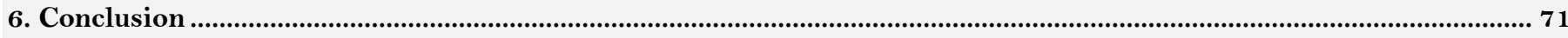

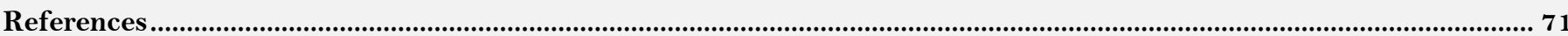




\section{Background}

Taxation in Indonesia comes from three main objects namely income tax, value added tax and property taxes: income tax in article 4 of Law No. 38 in 2008, stated that the income that each additional economic capability received or accrued by the taxpayer, whether originating from Indonesia and outside Indonesia, which can be used for consumption or to increase the wealth of the taxpayer, with the name and in whatever form, including:

1. Or remuneration in respect of employment or services received or acquired, including salaries, allowances, fees, commission, bonus, gratuity, pension, or other forms of remuneration, unless otherwise provided in this Act.

2. Prize of the lottery, work or activities, and awards.

3. Operating profit.

4. Gains from the sale or transfer of property including.

Value Added Tax (VAT), VAT objects can be grouped into two kinds: Taxable Goods (BKP) and taxable services (JKP). Value added tax (VAT) taxes imposed in terms of their:

1. Submission BKP / JKP in the customs area (dp) conducted by entrepreneurs.

2. Import BKP.

3. Utilization of Intangible BKP inside and out dp dp,

4. Utilization JKP inside and outside dp dp.

5. Export BKP by PKP.

Land and Building Tax (PBB) is a tax levied on land and or building based on Law No. 12 of 1985 on Land and Building Tax as amended by Act No. 20 of 2000 (Abdillah and Mursinto, 2016). The UN is a tax that is immaterial in the sense of the magnitude tax payable is determined by the state of the object, namely earth, land and or building. The state of the subject (who pays) are the ones to determine the amount of tax. While the UN object is "Earth and or Building": Earth: the Earth's surface (land and water) and body earth beneath. Example: fields, fields, gardens, land, yard. mining, and others. Building Construction techniques are implanted or permanently attached to the land or waters in the territory of the Republic of Indonesia. Examples: residential houses, business buildings, high rise buildings, shopping centers, highways, swimming pools, offshore oil, and others (Shofiana, 2011). The excluded objects are objects that:

1. Used solely to serve the public interest in the field of religious, social, education and national culture are not intended to benefit, such as mosques, churches, government hospitals, schools, orphanages, temples, and others.

2. Used for graves, ancient heritage.

3. A protected forest, nature reserve, jungle, national parks, and others.

4. Owned by diplomatic representatives based on the principle of reciprocity and international organizations determined by the Ministry of Finance.

The subject of tax is an individual or entity that is real:

1. Have a right to the earth, and or

2. Benefit on earth, or

3. Possess, control over the building, and or

4. Obtain benefit from the building.

Object and subject of various sources of tax revenue in Indonesia, we also need to look at the state budget (APBN) from 2012 until 2016, for the tax revenue in Indonesia continues to increase until the tax revenue in 2016 reached 1539.2 trillion rupiah (Table 1 ).

Table-1. Budget Developments 2012-2017 (In trillion rupiah)

\begin{tabular}{l|l|l|l|l|l|l}
\hline \multicolumn{7}{c}{ Table-1. Budget Developments 2012-2017 (n trillion rupiah) } \\
\hline $\begin{array}{l}\text { Shopping } \\
\text { Central government }\end{array}$ & $\mathbf{2 0 1 2}$ & $\mathbf{2 0 1 3}$ & $\mathbf{2 0 1 4}$ & $\mathbf{2 0 1 5}$ & $\mathbf{2 0 1 6}$ & 2017 Draft Budget \\
\hline $\begin{array}{l}\text { Transfer to Regional \& Rural } \\
\text { Fund }\end{array}$ & $480.6 \mathrm{~T}$ & $513.3 \mathrm{~T}$ & $573.7 \mathrm{~T}$ & $623.1 \mathrm{~T}$ & $776.3 \mathrm{~T}$ & $760.0 \mathrm{~T}$ \\
\hline Tax Revenues & $1137.6 \mathrm{~T}$ & $1203.6 \mathrm{~T}$ & $1183.3 \mathrm{~T}$ & $1306.7 \mathrm{~T}$ & $1310.4 \mathrm{~T}$ \\
\hline Non-tax revenue & $980.5 \mathrm{~T}$ & $1077.3 \mathrm{~T}$ & $1146.9 \mathrm{~T}$ & $1240.4 \mathrm{~T}$ & $1539.2 \mathrm{~T}$ & $1495.9 \mathrm{~T}$ \\
\hline State Funding & $351.8 \mathrm{~T}$ & $354.7 \mathrm{~T}$ & $398.6 \mathrm{~T}$ & $255.6 \mathrm{~T}$ & $245.0 \mathrm{~T}$ & $240.3 \mathrm{~T}$ \\
\hline Source: Draft Budget 2017 & $175.2 \mathrm{~T}$ & $237.4 \mathrm{~T}$ & $248.9 \mathrm{~T}$ & $323.1 \mathrm{~T}$ & $296.7 \mathrm{~T}$ & $332.8 \mathrm{~T}$ \\
\hline
\end{tabular}

State Budget (APBN) of the tax revenue continued to increase and was the biggest revenue of the other receipts it needs to be seen also how the allocated budget for the State of the State Budget 2016 and comparison of tax revenue and the number of poor people in Indonesia (Shofiana, 2011). The allocation of tax revenue distribution in Indonesia, which is used to increase the economic growth of the State expenditure in 2016 amounted to 2095.7 billion state budget, the type of expenditure or allocation of government expenditure consists of:

1. Shopping ministry or agency 784.1 trillion

2. Shopping transfers to regions and villages of 770.2 trillion

3. Shopping non ministry or agency of 541.4 trillion

From the above data concluded that the largest source of revenue comes from the Indonesian state taxes while the biggest expenditure allocation on shopping ministry or agency of 784.1 trillion, larger than transfers to the shopping area and the village of 770.2 trillion (Kemenkeu.go.id/APBN 2016).

So from this data needs to be studied and see how the level of poverty in Indonesia from Table 2 below: 
Table-2. Comparison of Revenue and Number of Poor People in Indonesia

\begin{tabular}{l|l|l|l}
\hline Year & Tax revenue (Billion rupiah) & Year & Number of Poor People (Million People) \\
\hline 2010 & 723 & 2010 & 31.02 \\
\hline 2011 & 873 & 2011 & 30.02 \\
\hline 2012 & 980 & 2012 & 29.33 \\
\hline 2013 & 1077 & 2013 & 28.59 \\
\hline 2014 & 1246 & 2014 & 27.73 \\
\hline 2015 & 1489 & 2015 & 28.59 \\
\hline 2016 & 1539 & 2016 & 28.01 \\
\hline Source: & $\begin{array}{l}\text { Memorandum of Finance and the State Budget of } 2013, \\
\text { 2. Memorandum of the Finance and Draft Budget 2016 } \\
\text { 3. Statistics Indonesia }\end{array}$ \\
\end{tabular}

Tax which would be a solution to poverty, have not been able to be a transfer of wealth from the rich and the poor (the regulator), the new tax is only capable of being a source of state income (budgetary) only, to fund various government requirements (Sacchi and Salotti, 2011). Can be seen (Table 2) above since 2010 through 2016 tax revenue in billions of rupiah continues to increase is high, but the rate of the number of poor from 2014 to 2015 experienced a high increase. In 2015, the number of poor people in Indonesia reached 28.59 million increased by 0.86 million compared with conditions in 2014, which amounted to 27.73 million, and in 2016 reached 28.01 million decreased \$ 500 million compared 2015. Tax revenues are increasing not accompanied by decreasing the amount of poverty in Indonesia. So it can be analyzed that the tax cannot be applied increase economic growth and lead to inequality region which is a burden to areas not yet ready with the economic situation and low growth (Silver, 2017). Based on data from the State Budget (APBN) of tax revenue and the number of poor people in Indonesia above need to be seen again how the growth of capital income in Indonesia (Figure 1), the growth capital income of Indonesia in 2000 until 2014, the average income are capital in Indonesia years 2000-2014 is based on three neighboring countries of Malaysia, Thailand and the Philippines, are known to Indonesia's capital income in 2014 amounted to an average of US \$ 3,475 dollars capital income far below Malaysia at 10538 US \$ dollars and Thailand 5779 US $\$$ dollars. And from the comparison of income above can be seen massive category Indonesia's capital income (Table 3), when viewed Indonesia's capital income growth in 2014 were an average of 3.475 US \$ meaning Indonesia's capital income in the category of middle income.

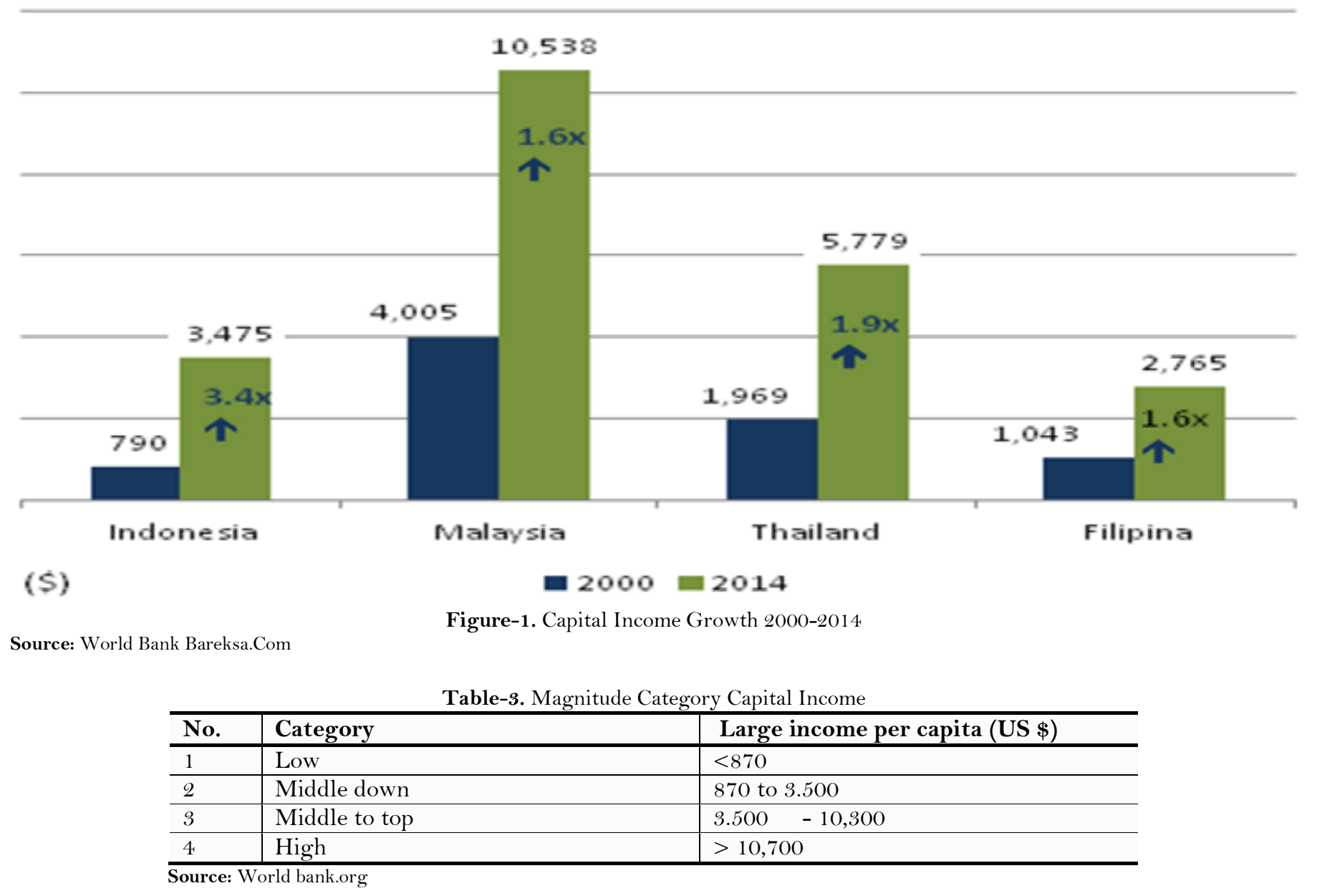

Can also unknown how the details of economic growth in the 33 provinces in Indonesia (Table 4), the highest economic growth is still in Java amounted to 1407.1 on quadran to four in 2016, and economic growth is the lowest in Maluku and Papua at 68.7 in quadran to four in 2016. it can be seen that economic growth in Indonesia is still very uneven and unequal once seen from the comparison between Java, Maluku and Papua. 
Table-4. Gross Regional Domestic Product Details 33 Provinces in Indonesia (Top of Constant Prices)

\begin{tabular}{|c|c|c|c|c|c|}
\hline \multirow{2}{*}{ Region } & \multirow{2}{*}{ Unit } & \multicolumn{4}{|l|}{2016} \\
\hline & & Q1 & Q2 & Q3 & Q4 \\
\hline SUMATRA & (Rp Trillion) & 496.49 & 507.05 & 521.4 & 520.3 \\
\hline Aceh & (Rp Trillion) & 28.41 & 28.61 & 29.6 & 29.8 \\
\hline North Sumatra & (Rp Trillion) & 113.33 & 114.50 & 117.9 & 118.0 \\
\hline West Sumatra & (Rp Trillion) & 35.94 & 36.79 & 37.6 & 37.8 \\
\hline Riau & (Rp Trillion) & 110.64 & 112.59 & 116.2 & 119.6 \\
\hline Jambi & (Rp Trillion) & 31.78 & 32.35 & 32.8 & 33.6 \\
\hline South Sumatra & (Rp Trillion) & 64.28 & 66.58 & 69.1 & 66.8 \\
\hline Bengkulu & (Rp Trillion) & 9.79 & 9.91 & 10.1 & 10.3 \\
\hline Lampung & (Rp Trillion) & 51.07 & 53.30 & 55.1 & 50.4 \\
\hline Kep. Bangka Belitung & (Rp Trillion) & $11: 58$ & 11.90 & 12.1 & 12.3 \\
\hline Riau islands & (Rp Trillion) & 39.67 & 40.52 & 41.1 & 41.6 \\
\hline JAVA & (Rp Trillion) & 1338.58 & 1381.27 & 1417.9 & 1407.1 \\
\hline DKI Jakarta & (Rp Trillion) & 372.30 & 381.85 & 390.4 & 394.8 \\
\hline West Java & (Rp Trillion) & 307.35 & 319.63 & 325.9 & 322.7 \\
\hline Central Java & (Rp Trillion) & 205.99 & 212.43 & 218.1 & 212.9 \\
\hline In Yogyakarta & (Rp Trillion) & $21: 37$ & $21: 39$ & 22.5 & 22.4 \\
\hline East Java & (Rp Trillion) & 337.85 & 349.75 & 362.5 & 355.1 \\
\hline Banten & (Rp Trillion) & 93.72 & 96.22 & 98.5 & 99.2 \\
\hline BALI NUSRA & (Rp Trillion) & 69.62 & 72.21 & 75.7 & 74.0 \\
\hline Bali & (Rp Trillion) & 32.93 & 33.95 & 35.0 & 35.3 \\
\hline West Nusa Tenggara & (Rp Trillion) & 22.64 & $23: 56$ & 25.2 & 23.1 \\
\hline East Nusa Tenggara & (Rp Trillion) & $14: 05$ & 14.70 & 15.5 & 15.5 \\
\hline KALIMANTAN & (Rp Trillion) & 197.65 & 199.63 & 203.6 & 207.0 \\
\hline West Kalimantan & (Rp Trillion) & 29.22 & 28.40 & 30.1 & 30.4 \\
\hline Central Kalimantan & (Rp Trillion) & $20: 40$ & $20: 59$ & 21.2 & 21.7 \\
\hline South Kalimantan & (Rp Trillion) & 26.93 & 29.05 & 30.1 & 29.6 \\
\hline East Kalimantan & (Rp Trillion) & 108.59 & 108.95 & 109.3 & 112.2 \\
\hline North Kalimantan & (Rp Trillion) & $12: 52$ & 12.64 & 12.9 & 13.1 \\
\hline SULAWESI & (Rp Trillion) & 132.30 & 140.56 & 146.1 & 145.0 \\
\hline North Sulawesi & (Rp Trillion) & 16.95 & $18: 24$ & 19.1 & 20.5 \\
\hline Central Sulawesi & (Rp Trillion) & $22: 22$ & $23: 05$ & 22.7 & 23.1 \\
\hline South Sulawesi & (Rp Trillion) & 63.12 & 67.44 & 71.3 & 67.5 \\
\hline Southeast Sulawesi & (Rp Trillion) & 17.92 & $19: 32$ & 19.9 & 20.6 \\
\hline gorontalo & (Rp Trillion) & 5.72 & 5.72 & 6.1 & 5.9 \\
\hline West Sulawesi & (Rp Trillion) & $6: 37$ & 6.78 & 7.0 & 7.4 \\
\hline MALUKU AND PAPUA & (Rp Trillion) & 54.69 & 56.87 & 64.8 & $\begin{array}{llll}68.7 & & & \\
\end{array}$ \\
\hline Moluccas & (Rp Trillion) & $6: 30$ & $6: 50$ & 6.6 & 6.9 \\
\hline North Maluku & (Rp Trillion) & $5: 18$ & $5: 34$ & 5.5 & 5.6 \\
\hline West Papua & (Rp Trillion) & $13: 43$ & $13: 04$ & 13.9 & 14.3 \\
\hline Papuan & (Rp Trillion) & 29.79 & 31.99 & 38.8 & 41.9 \\
\hline
\end{tabular}

\section{Problem}

From the above background can be seen the tax revenue continues to increase, however, is not matched by an increase in income per capita of Indonesian society, and when seen from a comparison category revenues level in the category of medium, based on the allocation of the distribution of tax revenue in Indonesia, the allocation of expenditure ministry or agency, greater than the allocated budget for transfers to the regions and villages. And can also be seen from a comparison of economic growth or the 33 provinces where the disparity in economic growth imbalances between each island and province very far away.

From the conclusions above problems it is necessary to analyze how the effect of economic growth by entering the well of tax revenue to the income disparity in Indonesia, studied in perspective the Islamic economy? because the applicable tax in Indonesia sometimes levied on poor people and businesses who are just starting to grow or employers who have not benefited from his efforts, and there is no difference in taxation between people who are not able and capable, as well as on the United Nations (Tax and Building) where the tax revenue will still be divided for central and local government, so that it becomes an influence on the amount of parts to be received by each of the areas which cause disparities.

\section{Theory}

Analysis Keynes in The General Theory, argued that the government can use the power of taxation and expenditure to increase spending aggregate (or stimulate aggregate expenditure). That power can be based on the condition of the government or its purpose, namely in times of recession or depression and are contractionary and expansionary.

Peacock and Wiseman stated that the economic growth (GDP) led to increased tax collection despite the tax rate unchanged. The tax increase came from extending the tax. In addition, the increase in tax revenue caused government spending also increased. Therefore, under normal circumstances, the rise in GDP led to acceptance of greater government revenue, as well as government spending increases.

\section{Tax}

According to Prof. Dr. H. Rochmat Soemitro, SH. Tax is a cash contribution to the people of the state based on law (enforceable) does not receive the services of lead (contra) directly demonstrated to those used to pay for general expenses, so that the people's taxes are dues to the treasury countries that can be imposed, meaning that if the tax debt is not paid then the taxpayer may incur penalties can even be treated imprisonment (Khoirul and Nugraheni, 2016).

According to tax is a mandatory fee in the form of goods levied by the authorities based on legal norms, in order to cover the cost of production of goods and services collectively to achieve common prosperity. 


\section{Taxes in the View of Islam}

Taxes in the view of Islam generally means a payment made to the government to finance expenditures that do in terms of organizing services for the public interest. And the Islamic economic system of tax must satisfy four elements that must be the Nash (Quran and Hadith) are ordered each source and the collection, tax collection system or charity should ensure that only the rich and the group prosperous that had the ability who bear the burden for their main demands of the common good (Khoirul and Nugraheni, 2016). Etymologically taxes in Arabic known as dharibah derived from the root word dharoba, yadhribu, dharban meaning; obliging, establish, determine, hitting, explain or charge and others. Dharaba is a form of the verb, whereas in the form of a noun is dharibah which means the load. Known as an obligation additional burden on property other than zakat so that the implementation will be perceived as a burden. How kharaj and jizya? The object of kharaj is ground, then if used term tax for kharaj the Islamic economic system would be confused by the term taxes on income or revenue, in Islamic taxes, referred to as kharaj a type of tax levied on land, especially conquered by force of arms, regardless of whether the owner was a person under age, an adult, a free, slaves, Muslims or non-Muslims. Similarly, the jizya, the object is the soul, not the same as dharibah (Akita and Pagulayan, 2014).

Originally applied to tax under Islam Ibn Taymiyyah said: "There is no contradiction in the hadith, because zakat and other liabilities other than zakat (tax) is caused by different reasons. Reason enactment of zakat is due to own property above the maximum limit (ratio) while the enactment of tax reasons is not because it has excess property, but because of the emergence of an urgent need in the community". Tax is only levied according to the amount of financing required, cannot exceed. And taxes can be removed when they are not needed (Obaidullah, 2008).

Silver (2017) has argued that the tax is a treasure that is required Allah to the Muslims to finance various needs and expenditure items that are required of them, on condition of Baitul Mal no money / possessions, thus summed up five key elements is an important element which must be included in the tax provision by law, namely: 1. Required by Allah SWT

2. The object is a treasure (Al-Maal)

3. Muslims rich subject (ghaniyyun) only

4. The goal is simply to finance them (Muslims) only

5. Imposed only because of emergency conditions (specifically) that must be overcome by ulil Amri.

\section{Economic Growth}

Disparity can be seen not only influenced by the growth of per capita income alone but can also be influenced by economic growth as measured by the growth of GNP, because by including economic growth as measured by gross domestic product, into the model Simon Kuznets shows the contradiction relationship between economic growth and disparity income, the contradiction is due to the disparity of income and economic growth are equally outcome variable is not a policy variable (Silver, 2017).

Factors that impact directly on economic growth and income disparity but are mediators that factors of production labor, capital and technology In this study the factors that are used as the cause of economic growth and income disparities are focused on government expenditure, using capital factor expressed with the government's revenue from taxes (Abdillah and Mursinto, 2016).

\section{Disparity}

Disparity or inequality region is one of the problems that inevitably arise in development. Inequality region becomes significant when the region within a country occur on a variety of potential natural resources, geographical location, quality of human resources and ethnic ties or political. One way to reduce inequality in the region is to organize the construction. But development is not necessarily to reduce the inequality of the region. Therefore, it is important to put forward the concept of equity in development in Indonesia (Dwamena, 2012).

The purpose of economic development is to create growth and changes in the economic structure, social change, alleviating poverty, reduce disparities and unemployment (Rozycki, 2017).

Economic development should be helped to overcome inequality of the tax to be one of the biggest reception were very influential to the State. From the standpoint of fiscal, tax is state revenue is used to improve the welfare of the people with the basic principles of collecting funds obtained from and to the community through mechanisms that refers to the legislation in force, the results of the tax revenue is later used for various purposes of local government especially for building area. Given the importance of the contributions made by tax revenue for financing the construction of the collection of the UN should be done effectively, because if the levies set of taxation not in accordance with the abilities of each region will be one of the causes of inequality or disparity in the region who feel burdened by their tax. The negative impact of inequality extreme among other inefficiencies in the economy, weakening of social stability and solidarity, as well as high inequality are generally seen as unfair, while the positive impact of inequality is the impact to encourage other regions that are less developed to be able to compete and increase growth in order to improve their welfare (Shaikh, 2012). Many programs have been developed to reduce disparities, disparities between regions so far apparently not achieve sufficient results because of the development budget allocation area is as an instrument to reduce disparities, then what if the tax imposed on the community is to be an influence disparity for the local community or region to advanced, due to economic growth vary by region so that the tax is charged at each area it causes imbalance. Disparity or inequality between regions due to the mobilization of resources owned by an area. Such resources include the accumulation of capital, labor, and natural resources are owned. Heterogeneity and diverse characteristics of an area leads to a tendency inequality between regions (McCartney, 2011). Somon Kuznets assume that higher income groups contribute capital and big savings, while capital from other groups is very small, whereas the same conditions, then the difference in saving ability will affect the concentration of increasing the proportion of income in the higher income groups. This process accumulative impact that further enhance the capabilities in high-income groups, then will increase income inequality within a country (Sun and Chai, 1998). 


\section{Measurement of Regional Disparities}

The size of inequality used to use this measure introduced by Williamson (1965) the calculation of this value is based on the index variation modifies this calculation to weigh the proportion of the region's population. Unlike the Gini index that calculates the value of the entire household income distribution in a region or country, Williamson index can see the magnitude of inequality of income distribution between regions within a region. The greater the Williamson index number, the greater the degree of inequality. This index can be calculated using the formula:

Where :

$$
I W=\frac{\sqrt{\left(Y_{i}-\widehat{Y}\right) \frac{f_{i}}{n}}}{\widehat{Y}}
$$

IW : Income disparity index

fi : The total population of each province i

$\mathrm{n}$ : Number of national population

$\mathrm{Y}_{\mathrm{i}} \quad$ : The GDP of each province $\mathrm{i}$

$\widehat{Y} \quad$ : On average the GDP

disparity index restriction between regions using this size, namely:

1. The index value $>1$, the maximum inequality occurs

2. The index value from 0.7 to 1 , there is high inequality

3. The index value from 0.4 to 0.6 , an imbalance that is being

4. The index value $<0.3$, there is a low inequality

\section{Research Methods}

This study further develops Kuznets models that have been developed by Chang and Rati Ram. Development is done by mensubtitusikan variable by variable tax revenue growth, with the model:

$$
\mathbf{D P}_{i t}=\mathbf{F}\left(\mathbf{Y}_{\mathrm{it}}, \mathbf{T}_{\mathrm{it}}\right) \text {. }
$$

(persamaan 2)

Where :

DP: Diparitas Revenue

Y: GRDP provinces in Indonesia

Q: Tax Revenue in Indonesia

Sacchi and Salotti (2011) to analyze the data collected will be used the econometric model. The analytical method used is descriptive qualitative and quantitative analysis. Qualitative descriptive analysis is used to describe the phenomena related to the problems studied. While quantitative used to analyze the quantitative information (data that can be measured, tested and transformed in the form of equations, tables and so on). Quantitative analysis stage consists of the estimated regression model with panel data usage, multiple linear regression equation using PLS (Pooled Least Square), the classic assumption test and statistical tests.

\section{Discussion}

Dependent Variable: PE?

Method: Pooled Least Squares

Sample: 200142016

Included observations: 3

Cross-sections included: 33

Total pool (balanced) observations: 99

Table-4. Empirical Results

\begin{tabular}{l|l|l|l|l}
\hline variable & coefficient & Std. Error & t-Statistic & Prob. \\
\hline $\mathrm{DP}$ & -12.34665 & 11.18783 & -1.103579 & 0.2755 \\
\hline $\mathrm{Y}$ & -0.136035 & 0.040675 & 3.344420 & 0.0016 \\
\hline $\mathrm{T}$ & 0.915000 & 0.902074 & 1.014330 & 0.3157 \\
\hline \multicolumn{7}{l}{ Effects Specification } & & \\
\hline Cross-section fixed (dummy variables) & \multicolumn{2}{l}{ Mean dependent var } & \\
\hline R-squared & 0.714340 & SD dependent var & 1.212145 \\
\hline Adjusted R-squared & 0.633611 & Akaike information criterion & 2.419566 \\
\hline SE of regression & 0.733713 & Schwarz criterion & 2.908246 \\
\hline Sum squared resid & 24.76339 & Hannan-Quinn criter. & 2.610715 \\
\hline Log likelihood & -58.58697 & Durbin-Watson stat & 1.297111 \\
\hline F-statistic & 8.848525 & & \\
\hline Prob (F-statistic) & 0.000000 & \multicolumn{2}{l}{}
\end{tabular}

After performing regression testing obtained panel data regression model for the disparity in revenue 33 provinces in Indonesia:

$\mathrm{DP}=-12.34665-0.136036(\mathrm{Y})+0.915000(\mathrm{~T})$

Based on the three above equation. The negative sign means that economic growth if growth increases by one percent, the income disparity index decreased by 0:13. A positive sign in tax revenues means that if tax revenues increased one percent, the index increased by 0.91 dipartites revenue. Local tax revenue for local development is expected to reduce income disparities community or region. However, this study shows the positive effect on tax 
revenue dipasaritas income, with a significance level of 0.91 . When compared with the data of tax revenue in Indonesia (Table 2 ) above since 2010 through 2016 tax revenue in billions of rupiah continued to increase high but the number of poor people in Indonesia continues to increase, means that the results of this study may explain why the number of people poor in Indonesia continues to increase each year because of tax revenue obtained positive effect on the disparity, in other words, no tax revenue positive hedge against declining disparity or inequality in Indonesia.

\section{Need Integration in Taxes}

There needs to be integration between the tax and zakat, charity is worship that provisions exist in the texts, zakat position and the position is very strategic in building the welfare, alleviate poverty and improve the local economy, if the collection and distribution is managed in a trustworthy, transparent and professional.

Taxes when viewed in terms of Shariah relating to Islamic economics then obtained three matters related to land and building tax are:

1. There are texts of the Qur'an and hadith, when viewed from the side of the subject taxes Earth and building is clearly contrary to the sharia, because Muslims participate charged on land and or building they own, occupy and use, even though they are the owners of land and buildings contained the word of Allah in Quran.

2. Imposed only to the rich. Land and Building Tax is also required to separate the rich and the poor, because their tax obligations are attached to objects or buildings earth.

Land and Building Tax has no basis in sharia, as the principle of the above opinion. This can lead to the oppression and injustice to the Muslims, especially the weak. Muslims in Indonesia should not be levied Land and Building Tax (PBB) and including non-Muslims. Because the land they inhabit not including land kharijiyah. Kharaj including official state reception on non-Muslims over land khariyah, but because Indonesia is not including the land kharajiyah the UN should not be collected (Shofiana, 2011).

\section{Taxes, Poverty and Disparities}

Tax which would be a solution to poverty, have not been able to be a transfer of wealth from the rich and the poor (the regulator), the new tax is only capable of being a source of state income (budgetary) only, to fund various government requirements. Can be seen (Table 3) above since 2010 through 2016 tax revenue in billions of rupiah continues to increase is high, but the rate of the number of poor from 2014 to 2015 experienced a high increase. In 2015 , the number of poor people in Indonesia reached 28.59 million increased by 0.86 million compared with conditions in 2014, which amounted to 27.73 million soul and in 2016 reached 28.01 million decreased $\$ 500$ million compared to the year 2015 (Rozycki, 2017). Tax revenue and income sources of the greatest nation that ever-increasing taxes is not accompanied by decreasing the amount of poverty in Indonesia. So it can be analyzed that the tax cannot be applied increase economic growth and lead to inequality region which is a burden to areas not yet ready with the economic situation and low growth.

\section{Conclusion}

From the discussion above it can be concluded that the fiscal policy is a government policy that carried out by the financial sector includes revenues, expenditures and the country's sovereign debt.

Fiscal policy in the Islamic economic system provides an important input in the implementation of fiscal or tax discretion in Indonesia, because the tax Islam for Muslims have been defined obligations and rules.

In Islam also sets out how the source and the collection system. Where the taxation and zakat system must ensure that only the rich and affluent class who has the advantage bore the main burden (paying taxes) due to the demands of the common good.

Tax costs imposed on society seems fair and not burdensome to the community if charges apply according to the ability of each community, following the pattern of tax or zakat in Islam, so it will affect inequalities and poverty are decreasing in each region.

\section{References}

Abdillah, K. and Mursinto, 2016. Introduction. Theoretical Frameworks, 4(2): 405-414.

Akita, T. and M.S. Pagulayan, 2014. Structural changes and interregional income inequality in the Philippines, 1975-2009. Review of Urban \& Regional Development Studies, 26(2): 135-154. View at Google Scholar | View at Publisher

Dwamena, M.A., 2012. Stress and its effects on employees productivity-a case study of Ghana Ports and Habours authority, Takoradi. Commonwealth Executive Master of Business Administration. pp: 1-82.

Khoirul, H.M. and N. Nugraheni, 2016. The taxation in islamic law perspective. Academic Research International, 7(1): $214-221$.

McCartney, M., 2011. Pakistan, growth, dependency, and crisis. Lahore Journal of Economics, 16(Special Edition): 71-944. View at Google Scholar

Obaidullah, M., 2008. Islamic finance for micro and medium. International Conference on Inclusive Islamic Financial Sector Development: Enhancing Islamic Financial Services for Micro and Medium Sized Enterprises was, (February), 379.

Rozycki, G.S., 2017. Staying the course. American Surgeon, 78(6): 627-634.

Sacchi, A. and S. Salotti, 2011. Income inequality, regional disparities , and fiscal decentralization in industrialized coun tries (*). Workshop on Rgional and Urban Economics : Inequality and Regional Growth and Cohesion, (November), 14-15.

Shaikh, S., 2012. Examining theories of growth \&amp; development \&amp; policy response based on them from islamic perspective. Retrieved from https://mpra.ub.uni-muenchen.de/38530/.

Shofiana, D.E., 2011. Tax in Indonesia in islamic perspective. Entrepreneur, 2(2): 159-169. View at Google Scholar

Silver, 2017. Sustainable Development Policy Institute (SDPI).

Sun, H. and J. Chai, 1998. Direct foreign investment and inter-regional economic disparity in China. International Journal of Social Economics, 25(2/3/4): 424-447. View at Google Scholar $\mid$ View at Publisher

Williamson, J.G., 1965. Regional inequality and the process of national development: A description of the patterns. Economic Development and Cultural Change, 13(4, Part 2): 1-84. View at Google Scholar | View at Publisher 